\title{
Customers Satisfaction Towards the Services Provided in Kuala Lumpur International Airport, Malaysia
}

\author{
Mohani Abdul, Mohd Khairi Abdul Aziz \\ University Putra Malaysia, Serdang Selangor, Malaysia \\ Mastora Yahya \\ Poly-Tech MARA College, Kuala Lumpur, Malaysia
}

\begin{abstract}
This study is conducted to measure customers satisfaction from the five dimensions of service quality, which are empathy, tangibility, responsiveness, reliability, and assurance. A quantitative approach, using the gap-model-SERVQUAL, has been used in the survey to gauge the opinions of Kuala Lumpur International Airport (KLIA) customers chosen via convenient sampling. Based on 100 respondents picked from several parts of the airport, the self-administered questionnaires were distributed and collected on the same day. Statistical tests such as multiple regression and ANOVA were performed and the results obtained among others showed that tangible elements of KLIA are the most important determinant of customers satisfaction followed by the intangible elements such as empathy, responsiveness, assurance, and reliability. The results of this study will be helpful to the management of KLIA in their effort to continuously upgrade their services in improving the customer services.
\end{abstract}

Keywords: customer satisfaction, empathy, tangibility, assurance, responsiveness, reliability

\section{Introduction}

Customer satisfaction is the foundation of any successful business which leads to repeat purchase, brand loyalty, and positive word of mouth (Hoyer \& Maclnnis, 2001). Thus, customer satisfaction has a positive effect on an organization's profitability. The issue on customer satisfaction is closely related to the quality of services provided, which has become the focus for many hospitality-industry researchers. In particular, knowing that how customers perceive the quality of products and services and that how those perceptions affect their purchasing decisions is among the important issues for marketing executives. Satisfied customers would be most likely to rate positively the company's performance, which ultimately boosts the image or brand of the company.

Due to the complex construct of customer satisfaction, it has been defined in various ways (Besterfield, 1994; Barsky, 1995; Kanji \& Moura, 2002; Fecikova, 2004; Bennet \& Rundle-thiele, 2004). The distinction between customer satisfaction with tangible products and intangible service experiences can be identified by

Mohani Abdul, Ph.D., associate professor of Business Administration, Institute for Social Science Studies, University Putra Malaysia, Serdang Selangor, Malaysia.

Mohd Khairi Abdul Aziz, Bachelor student, Faculty of Economics and Management, Universiti Putra Malaysia, Serdang Selangor, Malaysia.

Mastora Yahya, Ph.D., senior lecturer, Poly-Tech MARA College, Kuala Lumpur, Malaysia.

Correspondence concerning this article should be addressed to Mohani Abdul, Institute for Social Science Studies, University Putra Malaysia, Serdang Selangor, Malaysia. E-mail: mohani@upm.edu.my. 
their inherent intangibility and perish ability, as well as the inability to separate production and consumption. Hence, customer satisfaction on services and goods may derive from or may be influenced by different factors, and therefore, these two commodities should be treated as separate and distinct (Veloutsou, Gilbert, Moutinho, \& Good, 2005).

In the absence of tangible evidence, researchers and managers of service firms believe that service quality involves a comparison of expectations with performance. Parallel to this idea, Gronroos (1982) developed a model in which he contended that consumers tend to compare their expectation of the service with their perceptions of the service they receive in evaluating service quality. He postulated that two types of service quality exist: technical quality, which involves what the customer is actually receiving from the service; and functional quality, which involves the manner in which the service is delivered.

This study specifically looks at the vibrant airport industry which is changing rapidly and the fact that air travelers are able to choose their airports of arrival and departure and require airport marketers to differentiate themselves through serving their customers' needs satisfactorily comparative to their competitors. Aviation trade publications and airport press releases provide convincing evidence that managers in the airport industry clearly understand the importance of their customers' perceptions of service quality (Tsai, Hsu, \& Chou, 2011; Kim \& Lee, 2010; W. G. Kim, Ng, \& Y. S. Kim, 2009; Bomenblit, 2002; Gooding, 1999).

KLIA is one of Malaysia Airport Holdings Berhad (MAHB) subsidiaries as well as Asia's major aviation

hubs, located 50 kilometers south of Kuala Lumpur, in Sepang, Selangor. It has a 100 $\mathrm{km}^{2}$ hectares in size and has been the world's largest airport with 4,000 meters long run-away. It has been declared as the 13th busiest airport in the world by passenger traffic, the seventh busiest airport in Asia that handled almost 27 million passengers and 670,000 metric tons cargo which makes it the 27th busiest airport by cargo traffic (Malaysia Airport Holdings Berhad, 2011). Located within the ambit of the Multimedia Super Corridor (MSC), KLIA is a comprehensive airport equipped with all the facilities needed for business, entertainment, and relaxation. KLIA is bordered by four main cities: Kuala Lumpur, Shah Alam, Seremban, and Malacca.

Tsaur, Chang, and Yen (2002) argued that quality in airline services is difficult to describe and measure due to its heterogeneity, intangibility, and inseparability. Hence, in this context, the gap-model (SERVQUAL) has been proposed as a valid and reliable evaluation method in airline service quality studies (Gilbert \& Wong, 2003; Park, Robertson, \& Wu, 2004). It is used to compare the perceptions of performance (P) to expectation (E), which has been widely used in past studies by various industries. Specifically, this study replicates the SERVQUAL measurement of Parasuraman, Zelthaml, and Berry (1991) in determining the existence of "service-gaps" in KLIA. This paper aims to analyze the relationship between the five dimensions of service quality (empathy, tangibility, responsiveness, reliability, and assurance) of the KLIA and its customers' satisfaction.

\section{Dimension of Service Quality}

There are various dimensions of service quality declared by previous researchers. Parasuraman, Zelthaml, and Berry (1985) identified 10 dimensions which were credibility, security, competence, courtesy, communication, understanding/knowing customers, access, reliability, responsiveness, and tangibility in their early studies. Subsequently, in 1988, they have narrowed the dimensions of service quality into five important dimensions: empathy, assurance, reliability, responsiveness, and tangibility. Briefly, the following sub-sections look at the definitions of these five dimensions which will form the constructs for this study. 


\section{Empathy}

Zeithaml, Parasuraman, and Berry (1988) defined empathy as care and the individual attention that the firm provides to its customers. While Hansen, Samuelsen, and Silseth (2008) defined it as the feeling and understanding of how a person personalizes compassion and kindness, and gave them the real understanding. However, Kotler (1999) and Bitner and Zeithaml (2003) interpreted empathy as an act of caring in providing individualized attention to customers.

\section{Tangibility}

Tangibility is defined as the appearance of physical facilities, equipment, personnel, and communication materials of the organization (Kotler, 1999; Bitner \& Zeithaml, 2003; Zeithaml, Parasuraman, \& Berry, 1990). In addition, Parvez (2005) noted that customers look for quality in the equipment, facilities, and communication materials that are being used by the organization in providing the services to its customers.

\section{Assurance}

Kotler (1999), Bitner and Zeithaml (2003), and Zeithaml et al. (1990) defined assurance as knowledge and courtesy of employees and their ability to convey trust and confidence.

\section{Responsiveness}

Responsiveness is defined as the willingness to help customers and provide prompt service (Kotler, 1999; Bitner, Booms, \& Tetreault, 1990), while Parvez (2005) added that the customer must see service provided as ready and be willing to perform their said service.

\section{Reliability}

Reliability is described as the ability to perform the promised service reliably and accurately (Kotler, 1999; Bitner \& Zeithaml, 2003; Zeithaml et al., 1990). In addition, Parvez (2005) stressed that customers want performance to be consistent and dependable.

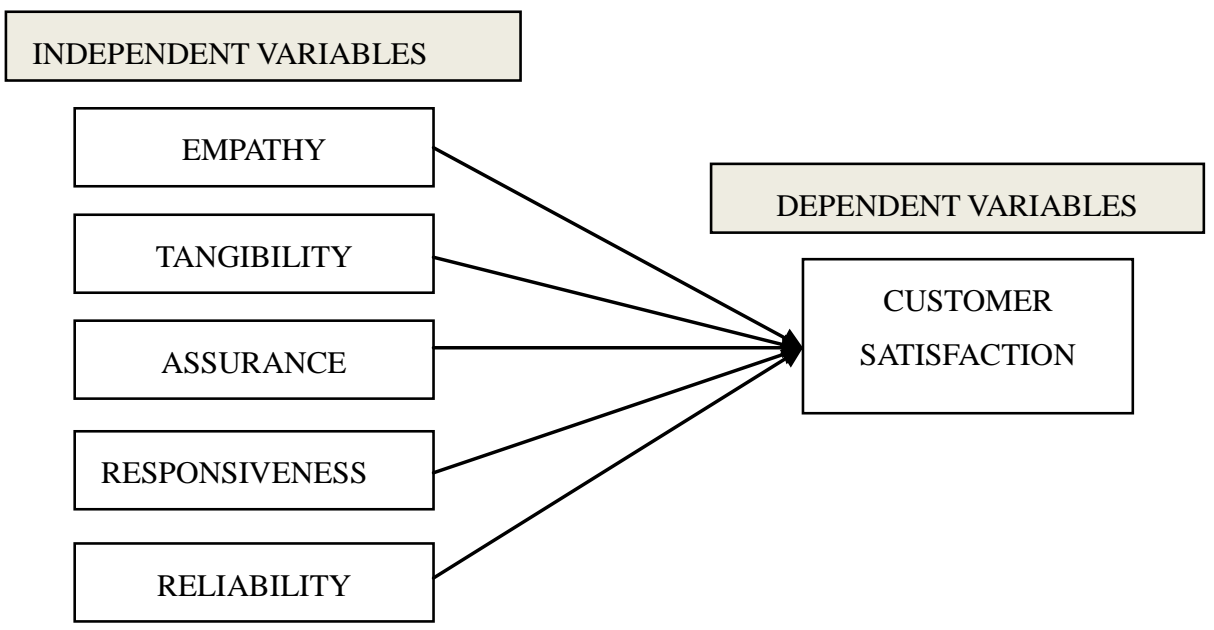

Figure 1. Theoretical framework.

\section{Literature Review}

Perceived value is an important determinant of customers' satisfaction and buying behavior. In gaining competitive advantages in the airline industry, some companies introduce value-added services such as frequent flyer programs which could increase the long-term value of consumers' relationship with the airline, offering 
greater benefits to repeat passengers than to occasional users (Dube \& Maute, 1998; Dennett, Ineson, Stone, \& Colgate, 2000).

Consumers' overall impression of service quality is linked to how efficiently an organization renders its services, and it is this impression that determines its customers' behavioral intentions to continuously patronize the airline or otherwise. Good service quality helps organizations to increase profits (Buzzel \& Gale, 1987) and maintain their competitive advantage within the specific industry (Park et al., 2004; Park, Robertson, \& Wu, 2005). Apart from the concern on competitive advantage, Mansor and Syed Redhwan (2012) in their study on KLIA stressed the importance of delivering efficient service not only for the development of the industry, but also to enhance the image of the nation as a whole. Since service quality and delivery are tangible, customers are able to compare good and poor service providers. Thus, it is important for airlines to develop passenger-focused services by making an effort to understand passengers' expectations (Park et al., 2004). Airlines also need to be aware of differences in service expectations among their passengers in different parts of the world and among different nationalities (Sultan \& Simpson, 2000; Cunningham, Young, \& Lee, 2002).

Since airline companies are very concerned about customers' loyalty, they need to review and reexamine their strategies not only to sustain customers' loyalty but also to remain competitive. Natalisa and Subroto (2003) suggested that domestic airline operators need to honor promises made in their promotional and external communication materials. Continuous training activities should also be provided to frontline operators, besides developing various kinds of loyalty programs to ensure unremitting customers' loyalty. Chin (2002) stated that an attractive frequent flier program (FFP) could actually contribute to increased loyalty from the repeat business of the rising number of customers. In addition, Dick and Basu (1994) suggested that reliability and confidence might encourage loyalty towards the service provider. Loyalty is very important to the survival of service companies, which can be depicted through customer behaviors such as repurchase intentions and purchasing sequence (Day, 1969) and attitudinal outcomes, such as recommending the service to others (Cronin \& Taylor, 1992; Zeithaml et al., 1990; Selnes, 1993).

\section{Methodology}

This study adopts the quantitative approach, where a survey was conducted in several parts of the KLIA. The respondents were stratified according to the stipulated criteria and the self-administered questionnaires were distributed accordingly.

\section{Sampling Procedures}

A convenient sampling was adopted whereby a sample of 100 respondents from several spaces in KLIA such as the departure hall, arrival hall, baggage carousel area, food court, waiting lounge, and many other parts of KLIA. They were asked to complete the self-administered questionnaires to provide accurate portrayal of characteristics understudied, for example, behavior, opinions, abilities, beliefs, and knowledge of the respondents (Burns \& Grove, 1993).

\section{Criteria of the Respondent}

In order to become a respondent for this study, the following criteria must be met: (i) They have already used the services provided by KLIA, (ii) they have experienced using services and facilities provided by KLIA, (iii) they are willing to participate, and (iv) they are 16 years and older. 


\section{Analysis of the Data}

The descriptive statistic was chosen to provide simple but meaningful analysis which can show pattern and trend in the opinion of the KLIA customers. However, the key focus is to meet the objectives of this research which is to determine the relationship between service quality dimension and customers' satisfaction as proposed by Parasuraman, Zelthaml, and Berry (1988). Some of the analyses done in this study are as follows: (i) Frequency and percentage is used to compare the travelling behavior of respondents; (ii) means and standard deviations are compared among the independent variables that relate to service quality, (iii) Pearson's correlation analysis is used to test any significant relationship between dependent and independent variables, and (iv) multiple regression is performed to test for significance of the regression model as a whole and the second significance test (ANOVA) is conducted to determine if the estimated parameters of each explanatory variable derived from the regression are statistically significance.

\section{Questionnaire}

The questionnaire consists of three sections in which: Section A aims to collect information on demographic data such as gender, age, marital status, and nationality; section B comprises four items which gauge information regarding respondent's traveling behavior; and section $\mathrm{C}$ is the most important section since it measures the relationships between the independent variables and dependent variable. Each variable has five items intended to measure the understudied phenomena.

\section{Results}

\section{Reliability of the Instrument}

The reliability of a measure is the extent to which the items measure the variable in a reliable, accurate, and unbiased manner (Cavana, Delahaye, \& Sekaran, 2001). According to Sayuti (2011), the reliability of a measure indicated the stability and consistency in which the instrument measures the concepts and helps to access the goodness of the measure. A Cronbach's Alpha value of 0.70 is deemed acceptable and thus reliable (Nunnally, 1978; Nunnally \& Bernstein, 1994; Sekaran, 2005; Hair, Black, Babin, \& Anderson, 2010). Table 1 below shows that all of the coefficient reliability is at the acceptable and reliable level.

Table 1

Reliability of the Data

\begin{tabular}{llcl}
\hline Variable & No. of item & Cronbach's Alpha & Results \\
\hline Empathy (IV1) & 5 & 0.814 & Good \\
Tangible (IV2) & 5 & 0.832 & Good \\
Assurance (IV3) & 5 & 0.819 & Good \\
Responsiveness (IV4) & 5 & 0.800 & Good \\
Reliability (IV5) & 5 & 0.907 & Very Good \\
Customer Satisfaction (DV) & 5 & 0.902 & Very Good \\
\hline
\end{tabular}

\section{Demographic Profile of Respondents}

Section A of the questionnaires solicits the demographic information of the respondents. There are four items asked: gender, age, nationality, and marital status of the respondent. Table 2 below appends the summary of frequencies and percentages of the demographic variables. Most of the respondents were males (65\%) and only $35 \%$ of them were females. In terms of age, most of them (40\%) aged between 21 to 30 years old, majority of whom are Malaysians (75\%) and are singles (50\%). 
Table 2

Demographic Variables of Respondents

\begin{tabular}{llll}
\hline Demographic variables & Category & Frequency & Percent \\
\hline \multirow{2}{*}{ 1. Gender } & Male & 65 & 65.0 \\
& Female & 35 & 35.0 \\
\hline \multirow{3}{*}{ 2. Age } & Below 20 & 20 & 20.0 \\
& Between 21-30 & 40 & 40.0 \\
& Between 31-40 & 30 & 30.0 \\
\hline \multirow{3}{*}{ 3. Nationality } & Above 41 & 10 & 10.0 \\
& Malaysian & 75 & 75.0 \\
& Non-Malaysian & 25 & 25.0 \\
4. Marital status & Single & 50 & 50.0 \\
& Married & 35 & 35.0 \\
\hline
\end{tabular}

\section{Respondents' Travel Behavior}

Section B of the questionnaire asked the respondents about their travel behavior. The questions precisely asked, how many times the respondents have traveled per month, for what purpose, name of the airline they usually travel, and the reasons for his or her choice of airlines.

Table 3 below shows the results of respondent's frequency of travelling per month, purpose of his/her travel, name of airline of his/her choice, and finally the reason for his/her choice of the airline. For frequency of the travelling, the highest frequency was in the range of zero to one times $(55 \%)$, followed by two to three times (25\%), four to five times (12\%), and only $8 \%$, of the respondents flew more than six times.

In terms of the respondents' purpose of travelling, the highest range was for holiday (45\%), followed by business or official (22\%), study (16\%), for urgent matters (11\%), and the remaining respondents chose for other purposes $(6 \%)$. Pertaining to the airline they usually used, 49 respondents (49\%) chose Air Asia, followed by other airline (46\%), Jet Star Airways (3\%), and Firefly and Emirates with one respondent each $(1 \%)$.

In the last item of respondents' travel behavior, they stated the reasons for their choice of airline. More than a third of the respondents (37\%) stated that they have selected the airlines for better service, followed by cheaper tickets offered (25\%), recommendation by others (16\%), familiarity (13\%), appealing sales promotion (6\%), and lastly other reason(s) with only $3 \%$.

Table 3

Respondents' Travel Behavior

\begin{tabular}{llcc}
\hline Travel behavior & Category & Frequency & Percent \\
\hline \multirow{3}{*}{ 1. Frequency travelled } & $0-1$ times & 55 & 55.0 \\
(per month) & $2-3$ times & 25 & 25.0 \\
& $4-5$ times & 12 & 12.0 \\
& 6 times and above & 8 & 8.0 \\
\hline \multirow{3}{*}{ 2. Purpose of travelling } & Business/official & 22 & 22.0 \\
& Holiday & 45 & 45.0 \\
& Study purpose & 16 & 16.0 \\
& Urgent matters & 11 & 11.0 \\
& Others & 6 & 6.0 \\
\hline
\end{tabular}


Table 3 to be continued

\begin{tabular}{llcc}
\hline Travel behavior & Category & Frequency & Percent \\
\hline \multirow{3}{*}{ 3. Name of airline } & Air Asia & 49 & 49.0 \\
& Firefly & 1 & 1.0 \\
& Jet Star Airways & 3 & 3.0 \\
& Emirates airlines & 1 & 1.0 \\
& Others & 46 & 46.0 \\
\hline \multirow{3}{*}{ 4. Reason for choice } & Appealing sales promotion & 6 & 6.0 \\
& Familiarity & 13 & 13.0 \\
& Recommendation & 16 & 16.0 \\
& Cheaper tickets & 25 & 25.0 \\
& Better services & 37 & 37.0 \\
\hline
\end{tabular}

\section{Descriptive Statistics}

The next section presents the descriptive statistics such as maximum, minimum, means, and standard deviation which were obtained for interval scale independent and dependent variables (Sekaran, 2003). Besides, descriptive statistics is used to described or summarize information about a population or sample (Zikmund, 2003) and therefore this allows observation in the trend of the respondents.

\section{Independent Variables:}

Empathy. Table 4 above shows the list of mean and standard deviation of the first independent variable of service quality which is empathy. The scale of the mean is based on five-point Likert scale. The first question-KLIA employees give individual attention-scored the highest mean with an average of 4.790. This indicates that passengers are satisfied with employees' attitude in providing individual attention, followed closely by the respondents agreeing on the KLIA employees dealing with them in a good manner (4.771) and the ability to solve the customers' problem (4.770). On the other two items which states "KLIA employees always make me feel special and important" and "employees of KLIA always understand my needs", the scores were 3.581 and 3.580 respectively.

Table 4

Empathy as Independent Variable

\begin{tabular}{|c|c|c|c|c|c|}
\hline Items & No. & Minimum & Maximum & Mean & Std. Deviation \\
\hline KLIA employees always give me an individual attention & 100 & 2.00 & 5.00 & 4.790 & 0.62434 \\
\hline $\begin{array}{l}\text { KLIA employees always deal with customers in a good } \\
\text { manner }\end{array}$ & 100 & 1.00 & 5.00 & 4.771 & 0.70861 \\
\hline $\begin{array}{l}\text { KLIA employees always make me feel special and } \\
\text { important }\end{array}$ & 100 & 3.00 & 5.00 & 3.581 & 0.63850 \\
\hline Employees of KLIA always understand my needs & 100 & 3.00 & 5.00 & 3.580 & 0.63850 \\
\hline $\begin{array}{l}\text { KLIA employees have the best interest at heart in } \\
\text { solving my problems }\end{array}$ & 100 & 1.00 & 5.00 & 4.770 & 0.70861 \\
\hline TOTAL & 100 & & & & \\
\hline
\end{tabular}

Tangibility. From Table 5, the accessibility of the airport's physical layouts (i.e. restaurants, restrooms, gates, and etc.) scored the highest mean 4.790 , followed by KLIA which has visually appealing facilities (4.770) and passengers agreeing that KLIA used modern equipment, with a mean score of 4.500. While the other two items on the confusion of excessive signage at the airport scored 4.740 and the neatness and professional 
appearance of KLIA employees scored the lowest 3.580. The irony is that the signage which is supposed to facilitate their movement in the airport has indeed confused them.

Table 5

Tangibility as Independent Variable

\begin{tabular}{|c|c|c|c|c|c|}
\hline Items & No. & Minimum & Maximum & Mean & Std. Deviation \\
\hline $\begin{array}{l}\text { An airport's physical layouts make me easy to find } \\
\text { what I need (i.e. restaurants, restrooms, gates, and etc) }\end{array}$ & 100 & 2.00 & 5.00 & 4.790 & 0.62434 \\
\hline KLIA used modern equipment & 100 & 1.00 & 5.00 & 4.500 & 0.83485 \\
\hline $\begin{array}{l}\text { Employees of KLIA have a neat and professional } \\
\text { appearance }\end{array}$ & 100 & 3.00 & 5.00 & 3.580 & 0.63850 \\
\hline KLIA has visually appealing facilities & 100 & 1.00 & 5.00 & 4.770 & 0.70861 \\
\hline $\begin{array}{l}\text { At the airports, the excessive number of signages } \\
\text { always confuses me. }\end{array}$ & 100 & 1.00 & 5.00 & 4.740 & 0.70525 \\
\hline TOTAL & 100 & & & & \\
\hline
\end{tabular}

Assurance. The means for all the items related to assurance (Table 6) are quite strong which indicate that the passengers agreed with the statement in the questionnaire. The highest mean is 4.730 for the item which the passengers felt safe in every transaction made by KLIA employees and the lowest mean is 3.540 which is "I am satisfied with the security inspection at KLIA".

Table 6

Assurance as Independent Variable

\begin{tabular}{|c|c|c|c|c|c|}
\hline Items & No. & Minimum & Maximum & Mean & Std. Deviation \\
\hline I trust airport employees & 100 & 3.00 & 5.00 & 4.710 & 0.53739 \\
\hline Employees of KLIA are consistently courteous & 100 & 1.00 & 5.00 & 4.690 & 0.70632 \\
\hline I am satisfied with the security inspection at KLIA & 100 & 3.00 & 5.00 & 3.540 & 0.59323 \\
\hline $\begin{array}{l}\text { Employees of KLIA always consult correct and } \\
\text { accurate information }\end{array}$ & 100 & 1.00 & 5.00 & 4.200 & 0.87617 \\
\hline $\begin{array}{l}\text { I always feel safe in every transaction made by KLIA } \\
\text { employees }\end{array}$ & 100 & 1.0 & 5.0 & 4.730 & 0.69420 \\
\hline TOTAL & 100 & & & & \\
\hline
\end{tabular}

Responsiveness. Table 7 below shows the means and standard deviations on the responsiveness of the KLIA employees. The highest mean is 4.771 where the respondents agreed that KLIA employees provide prompt service to their customers.

Table 7

Responsiveness as Independent Variable

\begin{tabular}{|c|c|c|c|c|c|}
\hline Items & No. & Minimum & Maximum & Mean & Std. Deviation \\
\hline $\begin{array}{l}\text { Employees at the airport always respond to my request } \\
\text { promptly }\end{array}$ & 100 & 2.00 & 5.00 & 4.660 & 0.68490 \\
\hline $\begin{array}{l}\text { Employees always willing to help customers whenever } \\
\text { they have problems }\end{array}$ & 100 & 1.00 & 5.00 & 4.640 & 0.73195 \\
\hline $\begin{array}{l}\text { Employees at an airport always keep me informed of } \\
\text { any changes that may occur. }\end{array}$ & 100 & 3.00 & 5.00 & 3.580 & 0.63850 \\
\hline $\begin{array}{l}\text { Employees of KLIA always respond to my complaints } \\
\text { immediately }\end{array}$ & 100 & 1.00 & 5.00 & 4.770 & 0.70861 \\
\hline $\begin{array}{l}\text { Employees of KLIA always provide prompt service to } \\
\text { customers }\end{array}$ & 100 & 1.00 & 5.00 & 4.771 & 0.70861 \\
\hline TOTAL & 100 & & & & \\
\hline
\end{tabular}


Reliability. Table 8 shows the list of mean and standard deviation for the items that measure reliability of the services provided. Many respondents agreed that KLIA airport is dependable and sympathetic, thus giving the item a score of 4.730. However, the item on the ability of the KLIA employees to solve their problems satisfactorily scored the lowest mean 3.550.

Table 8

Reliability as Independent Variable

\begin{tabular}{|c|c|c|c|c|c|}
\hline Items & No. & Minimum & Maximum & Mean & Std. Deviation \\
\hline $\begin{array}{l}\text { The airport management always provide me services as } \\
\text { they promised }\end{array}$ & 100 & .00 & 5.00 & 4.550 & 0.92524 \\
\hline $\begin{array}{l}\text { Employees of KLIA always reassuring me whenever I } \\
\text { have problem }\end{array}$ & 100 & .00 & 5.00 & 4.670 & 0.91071 \\
\hline $\begin{array}{l}\text { KLIA always provide services according to the } \\
\text { schedule }\end{array}$ & 100 & .00 & 5.00 & 3.550 & 0.72995 \\
\hline $\begin{array}{l}\text { Employees of KLIA are able to solve my problem with } \\
\text { satisfactory }\end{array}$ & 100 & .00 & 5.00 & 4.720 & 0.85375 \\
\hline $\begin{array}{l}\text { The KLIA airport is always reliable for the customer to } \\
\text { use its services }\end{array}$ & 100 & .00 & 5.00 & 4.730 & 0.85375 \\
\hline TOTAL & 100 & & & & \\
\hline
\end{tabular}

\section{Dependent Variable - Customer Satisfaction}

Table 9 below shows the list of means for items measuring the dependent variable, customer satisfaction. The highest mean is 4.790 which indicates that majority of the respondents are happy to use the service. The second highest mean is 4.780, where the respondents feel that the decision to use the KLIA service has been a wise decision. In general, the mean for the items in this section was quite high as compared to the other variables.

Table 9

Customer Satisfaction as Dependent Variable

\begin{tabular}{llllll}
\hline Items & No. & Minimum & Maximum & Mean & Std. Deviation \\
\hline I am happy that I used this service & 100 & 2.00 & 5.00 & 4.790 & 0.62434 \\
My choice to use this service was a wise one & 100 & 1.00 & 5.00 & 4.780 & 0.70891 \\
The service have worked out as well as I thought it & 100 & 3.00 & 5.00 & 3.580 & 0.63850 \\
would & 100 & 1.00 & 5.00 & 4.760 & 0.70361 \\
I will recommend KLIA services to other people & 100 & 1.00 & 5.00 & 4.774 & 0.70841 \\
I will continue using the services provided at KLIA & $\mathbf{1 0 0}$ & & & & \\
TOTAL &
\end{tabular}

\section{Pearson's Correlation Analysis}

The Pearson correlation table below determines the presence of the relationships between independent and dependent variable. The result of the correlation matrix is presented in Table 10 below. From the table, all variables are found to be significant and positively correlated.

There are five hypotheses proposed in this study. To test the first five relationships or hypotheses, all of them are supported. The results show that all variables are significant and positively related to customer satisfaction. All these variables, empathy $(r=0.954, p=0.000)$, tangibility $(r=0.969, p=0.000)$, assurance $(r$ $=0.392, p=0.000)$, responsiveness $(r=0.949, p=0.000)$, and reliability $(r=0.758, p=0.000)$, show moderate and substantial relationship towards customer satisfaction. 
Table 10

Pearson Correlation for the Independent Variables and Dependent Variable

\begin{tabular}{|c|c|c|c|c|c|c|c|}
\hline & & Empathy & Tangibility & Assurance & Responsiveness & Reliability & $\begin{array}{l}\text { Customer } \\
\text { Satisfaction }\end{array}$ \\
\hline \multirow{3}{*}{ Empathy } & $\begin{array}{l}\text { Pearson } \\
\text { Correlation }\end{array}$ & 1 & $0.940^{* *}$ & $0.426^{* *}$ & $0.921^{* *}$ & $0.743^{* *}$ & $0.954^{* *}$ \\
\hline & Sig. (2-tailed) & & 0.000 & 0.000 & 0.000 & 0.000 & 0.000 \\
\hline & $N$ & 100 & 100 & 100 & 100 & 100 & 100 \\
\hline \multirow{3}{*}{ Tangibility } & $\begin{array}{l}\text { Pearson } \\
\text { Correlation }\end{array}$ & & 1 & $0.388^{* * *}$ & $0.959^{* * *}$ & $0.732^{* *}$ & $0.969^{* *}$ \\
\hline & Sig. (2-tailed) & & & 0.000 & 0.000 & 0.000 & 0.000 \\
\hline & $N$ & & 100 & 100 & 100 & 100 & 100 \\
\hline \multirow{3}{*}{ Assurance } & $\begin{array}{l}\text { Pearson } \\
\text { Correlation }\end{array}$ & & & 1 & $0.392^{* * *}$ & $0.297^{* * *}$ & $0.392^{* *}$ \\
\hline & Sig. (2-tailed) & & & & 0.000 & 0.003 & 0.000 \\
\hline & $N$ & & & 100 & 100 & 100 & 100 \\
\hline \multirow{3}{*}{ Responsiveness } & $\begin{array}{l}\text { Pearson } \\
\text { Correlation }\end{array}$ & & & & 1 & $0.719^{* * *}$ & $0.949^{* * *}$ \\
\hline & Sig. (2-tailed) & & & & & 0.000 & 0.000 \\
\hline & $N$ & & & & 100 & 100 & 100 \\
\hline \multirow{3}{*}{ Reliability } & $\begin{array}{l}\text { Pearson } \\
\text { Correlation }\end{array}$ & & & & & 1 & $0.758^{* * *}$ \\
\hline & Sig. (2-tailed) & & & & & & 0.000 \\
\hline & $N$ & & & & & 100 & 100 \\
\hline \multirow{3}{*}{$\begin{array}{l}\text { Customer } \\
\text { Satisfaction }\end{array}$} & $\begin{array}{l}\text { Pearson } \\
\text { Correlation }\end{array}$ & $0.954^{* *}$ & $0.969^{* *}$ & $0.392^{* * *}$ & $0.949^{* *}$ & $0.758^{* * *}$ & 1 \\
\hline & Sig. (2-tailed) & 0.000 & 0.000 & 0.000 & 0.000 & 0.000 & \\
\hline & No. & 100 & 100 & 100 & 100 & 100 & 100 \\
\hline
\end{tabular}

Note. **. Correlation is significant at the 0.01 level (2-tailed).

\section{Multiple Regression Analysis}

Next, the multiple regression was performed to test for significance of the regression model as a whole and the second significance test is conducted to determine if the estimated parameters of each explanatory variable derived from the regression are statistically significance.

For the first significance test, the results of the analysis of variance (ANOVA) and the significance of the analysis depends on the value of $F$ which is the ratio between explained and unexplained variations of the dependent variable by all the explanatory variables. The $F$-ratio derived (437.623) was large enough to render the analysis of variance yielding a significant result at 0.01 level $(p=0.00)$, implying that the regression model as a whole is significant and can be reasonably accepted to represent the relationships between customer satisfaction and explanatory variables (empathy, tangibles, assurance, responsiveness, and reliability) in the population under study. The idea is to estimate variance explained in customer's satisfaction by five dimension of service quality (Sayuti, 2011). The five dimensions of service quality mentioned above are empathy, tangible, assurance, responsiveness, and reliability. The results were tabulated in Table 11 below.

The overall influence of service quality factors towards customer satisfaction is presented in Table 11 . The $R$ square value is 0.959 , which means that $95.9 \%$ of the variance in customer satisfaction has been significantly explained by the five dimensions of service quality. As such, the results of the study support the statement which states that service quality has significantly positive effects on customer satisfaction. The second significance test relates to the issue of whether the parameter estimates for each explanatory variable derived in 
the regression is statistically significance. For this purpose, regression analysis uses $t$-test as a measure of significance. Table 12 below summarizes the results.

Table 11

Model Summary

\begin{tabular}{lllll}
\hline Model & $\boldsymbol{R}$ & $\boldsymbol{R}$ Square & Adjusted $\boldsymbol{R}$ Square & Std. Error of the Estimate \\
\hline 1 & 0.979 & 0.959 & 0.957 & 0.11987 \\
\hline
\end{tabular}

Note. Predictors (constant), reliability (rc), empathy (rc), assurance (rc), and tangible (rc).

Table 12

Coefficients ${ }^{a}$ of the Explanatory Variable

\begin{tabular}{|c|c|c|c|c|c|c|}
\hline \multirow{2}{*}{\multicolumn{2}{|c|}{ Model }} & \multicolumn{2}{|c|}{ Non-standardized Coefficients } & \multirow{2}{*}{$\begin{array}{l}\text { Standardized Coefficients } \\
\text { Beta }\end{array}$} & \multirow{2}{*}{$t$} & \multirow{2}{*}{ Sig. } \\
\hline & & Beta & Std. Error & & & \\
\hline \multirow{6}{*}{1} & (Constant) & -0.209 & 0.125 & & -1.680 & 0.096 \\
\hline & Empathy & 0.361 & 0.075 & 0.316 & 4.835 & 0.000 \\
\hline & Tangibility & 0.501 & 0.090 & 0.482 & 5.570 & 0.000 \\
\hline & Assurance & -0.009 & 0.025 & -0.008 & -0.359 & 0.720 \\
\hline & Responsiveness & 0.172 & 0.084 & 0.155 & 2.043 & 0.044 \\
\hline & Reliability & 0.049 & 0.025 & 0.062 & 1.957 & 0.053 \\
\hline
\end{tabular}

Note. ${ }^{\text {a }}$ Dependent variable: Customer satisfaction.

From Table 12, tangibility of the service quality appeared to be the strongest explanatory variable in predicting customer satisfaction $(\beta=0.501, t=5.570)$ followed by empathy $(\beta=0.361, t=4.835)$ and responsiveness $(\beta=0.172, t=2.043)$. However, the results show that assurance and reliability have not been able to predict customer satisfaction significantly.

\section{Conclusions}

In this study, the results have shown that the tangible components of KLIA which include the physical appearance, equipment, personnel, and communication materials are the essential elements that lead to customers' satisfaction. Following that, empathy and responsiveness become the next important determinants that contribute to customers' satisfaction. However, assurance and reliability of the services in KLIA have not been able to satisfy its customers' satisfaction significantly. This confirms the importance of products' tangibility besides the perceived quality services provided to its customers in determining its customers' satisfaction. Hence, the KLIA management should focus on upgrading its employees' performance in delivering its services to the customers to promote satisfaction and brand loyalty. It is very crucial that the services provided by KLIA are not only accurate and reliable, but it must also provide the needed information timely. Another aspect of assurance which should be addressed is the issue of airport security inspection which the customers feel to be the weakest feature of the airport. The findings of this study if taken seriously would provide a good indication to the KLIA management as to which aspects of the services should be improved.

For future research, perhaps it would be useful to profile the respondents and conduct qualitative studies where certain issues can be further clarified. Another point of interest is that, although the opportunity to generalize this study on other airports is limited, there are lessons on customer satisfactions which other airport can learn from KLIA. 


\section{References}

Barsky, J. (1995). World-class customer satisfaction. Burr Ridge: Irwin Professional.

Bennet, R., \& Rundle-Thiele, S. (2004). Customer satisfaction not be the only goal. Journal of Marketing, 18, 514-523.

Besterfield, D. H. (1994). Quality control (4th ed.). London: Prentice Hall Intl., Inc..

Bitner, M. J., \& Zeithaml, V. A. (2003). Service marketing (3rd ed.). New Delhi: Tata McGraw Hill.

Bitner, M. J., Booms, B. H., \& Tetreault, M. S. (1990). The service encounter: Diagnosing favorable and unfavorable incidents. Journal of Marketing, 54, 71-84.

Bomenblit, A. (2002). Hong Kong international tops study. Business Travel News, 19, 6-6.

Burns, K. J., \& Grove, S. K. (1993). The practice of nursing research. Conduct, critique, and utilization. Philadelphia: Saunders.

Buzzel, R. D., \& Gale, B. T. (1987). The PIMS principles. New York: Free Press.

Cavana, R. Y., Delahaye, B. D., \& Sekaran, U. (2001). Applied business research: Qualitative and quantitative method. Melbourne: John Wiley \& sons.

Chin, A. (2002). Impact of frequent flyer programs on the demand for air travel. Journal of Air Transportation, 7(2), 53-86.

Cronin, J. J., \& Taylor, S. A. (1992). Measuring service quality: A reexamination and extension. Journal of Marketing, 56(3), $55-68$.

Cunningham, L. F., Young, C. E., \& Lee, M. (2002). Cross-cultural perspectives of service quality and risk in transportation. Journal of Air Transportation, 17(1), 3-26.

Day, G. S. (1969). A two dimensional concept of brand loyalty. Journal of Advertising Research, 9(3), 29-35.

Dennett, C., Ineson, E. M., Stone, G. J., \& Colgate, M. (2000). Pre-bookable services in the chartered airline industry: Increasing satisfaction through differentiation. Service Industries Journal, 20, 82-94.

Dick, A. S., \& Basu, K. (1994). Customer loyalty toward an integrated conceptual framework. Journal of Academy of Marketing Science, 22(2), 99-113.

Dube, L., \& Maute, M. F. (1998). Defensive strategies for managing satisfaction and loyalty in the service industry. Psychology and Marketing, 15, 775-791.

Fecikova, I. (2004). An index method for measurement of customer satisfaction. TQM Magazine, 16(1), 57- 66.

Gilbert, D., \& Wong, R. K. C. (2003). Passenger expectation and airline service: A Hong Kong based study. Tourism Management, 24, 519-532.

Gooding, R. (1999). London city airport takes service to new heights: Airport develops standards of service to monitor performance levels. World Airport Week, 6, 1-1.

Gronroos, C. (1982). An applied service marketing theory. European Journal of Marketing, 16(7), 30-41.

Hair, J. F., Black, W. C., Babin, B. J., \& Anderson, R. E. (2010). Multivariate data analysis (7th ed.). Englewood Cliffs: Prentice Hall.

Hansen, H., Samuelsen, B., \& Silseth, P. R. (2008). Customer perceived value in B-t-B service relationships: Investigating the importance of corporate reputation. Industrial Marketing Management, 37, 206-217.

Hoyer, W. D., \& Maclnnis, D. J. (2001). Consumer behaviour (2nd ed.). Boston: Houghton Mifflin Company.

Kanji, G., \& Moura, P. (2002). Kanji's business scorecard. Total Quality Management, 13(1), 13-27.

Kim, W. G., Ng, C. Y. N., \& Kim, Y. S. (2009). Influence of institutional DINESERV on customer satisfaction, return intention, and word-of-mouth. International Journal of Hospitality Management, 28, 10-17.

Kim, Y. K., \& Lee, H. R. (2010). Customer satisfaction using low cost carriers. Tourism Management, 32, $235-243$.

Kotler, P. (1999). Marketing management. New Delhi: Prentice-Hall.

Malaysia Airport Holdings Berhad. (2011). 2010-2011 Annual report, Sepang Selangor, Malaysia. Retrieved from ir.irchartnexus.com/malaysiaairports/reports.php?type=ar

Mansor, N., \& Syed Redhwan, S. A. M. (2012). Internationalization of service quality: A case of Kuala Lumpur International Airport, Malaysia. International Journal of Business and Behavioral Sciences, 2(12), 11-25.

Natalisa, D., \& Subroto, B. (2003). Effects of management commitment on service quality to increase customer satisfaction of domestic airlines in Indonesia. Singapore Management Review, 25(1), 85-104.

Nunnally, J. C. (1978). Psychometric theory (2nd ed.). New York: McGraw-Hill Inc..

Nunnally, J. C., \& Bernstein, I. H. (1994). Psychometric theory (3rd ed.). New York: McGraw-Hill.

Parasuraman, A., Zelthaml, V. A., \& Berry, L. L. (1985). A conceptual model of service quality. Journal of Marketing, 49, $41-50$. 
Parasuraman, A.; Zeithaml, V. A., \& Berry, L. L. (1988). A multiple-item scale for measuring consumer perceptions of service quality. Journal of Retailing, 64(1), 12-40.

Parasuraman, A.; Zeithaml, V. A., \& Berry, L. L. (1991). Refinement and reassessment of the SERVQUAL Scale. Journal of Retailing, 69, 140-147.

Park, J. W., Robertson, R., \& Wu, C. L. (2005). Investigating the effects of airline service quality on airline image and passengers future behavioral intentions: Findings from Australian international air passengers. The Journal of Tourism Studies, 16, 2-11.

Park, J. W., Robertson, R., \&. Wu, C. L. (2004). The effect of airline service quality on passengers' behavioral intentions: A Korean case study. Journal of Air Transport, 10(6), 435-439.

Parvez, M. (2005). A relationship study on service quality, switching cost, trust, customer satisfaction and customer loyalty in the context of grameephone (Independent University, Bangladesh).

Sayuti, S. A. (2011). Customer satisfaction towards service quality in RFC Restaurant: A case study in Kedah (Unpublished MSc. Thesis, UUM, Sintok, Kedah).

Sekaran, U. (2003). Research methods for business (4th ed). Hoboken: John Wiley \& Sons.

Sekaran, U. (2005). Research methods for business: A skill—Building approach (4th ed). New York: John Wiley \& Sons.

Selnes, F. (1993). An examination of the effect of product performance on brand reputation, satisfaction, and loyalty. European Journal of Marketing, 27, 19-35.

Sultan, F., \& Simpson, M. C. (2000). International service variants: Airline passenger expectations and perceptions of service quality. Journal of Services Marketing, 14(2/3), 188-216.

Tsai, W. H., Hsu, W., \& Chou, W. C. (2011). A gap analysis model for improving airport service quality. Total Quality Management, 22(10), 1025-1040.

Tsaur, S. H., Chang, T. Y., \& Yen, C. H. (2002). The evaluation of airline service quality by fuzzy MCDM. Tourism Management, 23, 107-115.

Veloutsou, C., Gilbert, R. G., Moutinho, L. A., \& Good, M. M. (2005). Measuring transaction specific satisfaction in services. European Journal of Marketing, 39(5-6), 606-628.

Zeithaml, V. A., Berry, L. L., \& Parasuraman, A. (1988). Communication and control processes in the delivery of service. Journal of Marketing, 52, 35-48.

Zeithaml, V., Parasuraman, A., \& Berry, L. (1990). Delivering quality service. New York: Free Press.

Zikmund, W. G. (2003). Business research methods (7th ed.). Mason: Thomson South-Western. 